\title{
OTVORITVENA KONFERENCA RAZISKOVALNE MREŽE EUROPEAN LITERACY NETWORK (ELN)
}

\section{Špela ARHAR HOLDT}

Trojina, zavod za uporabno slovenistiko

Filozofska fakulteta UL

Arhar Holdt, Š. (2015): Otvoritvena konferenca raziskovalne mreže European Literacy Network (ELN). Slovenščina 2.o, 3 (2): 45-5o.

URL: http://www.trojina.org/slovenscina2.o/arhiv/2015/2/Slo2.o_2015_2_o2.pdf.

\section{NAMEN ELN}

V sklopu evropskega finančnega mehanizma COST, ki podpira meddržavno in meddisciplinarno povezovanje evropskih raziskovalcev oz. raziskav, ${ }^{1}$ med leti 2015 in 2018 poteka tudi aktivnost IS1401: Strengthening Europeans' Capabilities by Establishing the European Literacy Network (ELN). ${ }^{2}$ Glavni namen aktivnosti je povezati raziskovalce, ki se na različnih področjih (jezikoslovje, pedagogika in specialna pedagogika, psihologija, medicina itd.) ukvarjajo z vprašanji branja in pisanja, primerjati pristope in rezultate ter razviti celostnejši pristop $\mathrm{k}$ problemom pismenosti - in raziskovanja pismenosti - v evropskem prostoru. Po uvodnih sestankih, na katerih so se začrtala osnovna delovna področja, je 8. in 9. novembra v Pragi potekala otvoritvena konferenca ELN.

\section{DELOVNI SKLOPI ELN}

Delovanje mreže ELN je organizirano v tri delovna področja oz. sklope. Prvi sklop (WP1) se ukvarja z vprašanjem inkluzije oz. vključevanja učečih se z motnjami branja in pisanja v (šolski) proces opismenjevanja. Sklop združuje raziskovalce, ki se posvečajo procesom, ki so predpogoj za uspešno

\footnotetext{
${ }^{1}$ Spletna stran COST: http://www.cost.eu/.

2 Predstavitev aktivnosti na strani COST: http://www.cost.eu/COST_Actions/isch/IS14.
} 
opismenjevanje, vprašanjem identifikacije specifičnih učnih težav, kot je disleksija, in razvojem metod, ki učencem s težavami lajšajo razvoj veščin, potrebnih za uspešno opismenjevanje oz. razvoj kompetenc za uspešno komuniciranje v družbi. Znotraj delovnega sklopa imajo raziskovalci možnost primerjati, kako k izzivom inkluzije pri opismenjevanju pristopajo različne evropske države, ter do kakšnih izsledkov je mogoče priti z metodološkimi pristopi različnih raziskovalnih disciplin. Primerjalni in povezovalni vidik različnih praks in metod odražajo tudi cilji delovnega sklopa, ki jih je mogoče prebrati na spletni strani: http://www.is1401eln.eu/en/working-groups/working-group-1/.

Drugi delovni sklop (WG2) združuje raziskovalce, ki se ukvarjajo z razvojnimi vidiki pismenosti $\mathrm{v}$ digitalnem svetu. Tematski poudarek sklopa je vseživljenjsko razvijanje veščin na področju pisanja in branja, ki v digitalnem svetu dobiva nove razsežnosti in možnosti, v evropskem prostoru pa je zlasti zanimiv v povezavi z vprašanjem večjezičnosti. Znotraj sklopa so se organizirale tri ekipe, ki se posvečajo različnim vidikom: digitalni pismenosti, večjezični pismenosti in razvoju veščin strokovnega oz. znanstvenega pisanja. Vendar pa je glede na opredeljene cilje mogoče tudi sodelovanje raziskovalcev drugih vsebinsko sorodnih področij: http://www.is1401eln.eu/en/workinggroups/working-group-2/.

Tretji delovni sklop ( $\mathrm{WG}_{3}$ ) se posveča tehnologijam za pismenost (ang. literacy technologies). Združuje strokovnjake, ki na eni strani razvijajo orodja za podporo opismenjevanju ali krepitvi veščin branja in pisanja na različnih stopnjah življenja, na drugi strani pa vire in orodja, ki omogočajo nove pristope $\mathrm{k}$ raziskovanju opismenjevanja in pismenosti. Ob identifikaciji dobrih praks in izmenjavi idej za nadaljnji razvoj področja je pomembna naloga delovnega sklopa zagotoviti čim boljšo seznanjenost javnosti z obstoječimi viri, orodji, podatkovnimi zbirkami in obenem poskrbeti za dostopnost ter izmenljivost raziskovalnih podatkov. Ekipe znotraj delovnega sklopa se bodo zato osredotočale na: pripravo inventarija obstoječih tehnologij za pismenost; validacijo obstoječih orodij; razvoj novih orodij in standarde, ki bodo omogočali 
izmenjavo podatkov na evropski ravni. Cilji sklopa so navedeni na strani: http://www.is1401eln.eu/en/working-groups/working-group-3/.

\section{TEMATSKI POUDARKI KONFERENCE}

Otvoritvena konferenca ELN je potekala v prostorih Filozofske fakultete Karlove univerze v Pragi. Prvi govorec na konferenci je bil vodja aktivnosti COST IS1401 Rui A. Alves (Univerza v Portu), ki je razglasil ustanovitev mreže ELN in napovedal principe njenega delovanja. Sledilo je krovno plenarno predavanje, v katerem je eden glavnih pobudnikov za organizacijo ELN, Malt Joshi (Univerza Texas A\&M), spregovoril o vlogi pismenosti v družbi, izzivih opismenjevanja v ZDA in tem, kako različni sistemi zapisovanja jezika vplivajo na opismenjevalno uspešnost.

Razmerje med govorjenim in pisnim jezikom, natančneje, kako ne/enoznačnost reprezentacije fonemov z znaki določenega jezika vpliva na branje in pisanje, je bilo tudi sicer ena pomembnejših tem na konferenci. Slovenščina v tem smislu velja za enega transparentnejših jezikov, medtem ko so jeziki, kjer je zapis fonemov zelo raznolik in manj predvidljiv (npr. angleščina ali danščina), za opismenjevanje večji izziv. O tej temi je govorila tudi vabljena govorka WP1, Karin Landerl (Univerza v Gradcu), ki je izpostavila, da omenjena razlika vpliva na način procesiranja besedila, zato jo je nujno upoštevati pri pripravi postopkov za identifikacijo težav, kot je disleksija.

Plenarni govorec WP2 Charles Bazerman (Univerza Kalifornije Santa Barbara) je predstavil vizijo raziskovanja vseživljenjske pismenosti, ki bi v idealnih pogojih kot longitudinalna študija spremljalo udeležence raziskave od prvega stika z jezikom, prek njihovega formalnega opismenjevanja in kasneje jezikovnega udejstvovanja v različnih življenjskih vlogah in žanrih. Kontinuiran in celosten pogled na razvoj in vlogo bralnih in pisalnih veščin $\mathrm{v}$ življenju posameznika bi omogočil določiti pomembne mejnike v razvoju teh veščin in optimizirati izobraževalni proces.

Plenarna govorka WP3 Ulla Richardson (Univerza Jyväskylä) je predstavila 
platformo GraphoGame, ki ponuja možnost razvijanja iger za pomoč pri učenju branja. Igre so različnih vrst in težavnostnih stopenj, v osnovi pa temeljijo na avtomatizaciji povezovanja med zvočno in pisno podobo jezika. GraphoGame obenem služi kot zbiralnik podatkov (o razvoju posameznega igralca, uspešnosti posamezne vrste igre za doseganje določenega cilja), ki omogočajo nadaljnji razvoj v igrah uporabljenih pristopov.

Poleg plenarnih predavanj smo prvi dan slišali še po tri izbrane predstavitve za vsakega od delovnih sklopov. Kot prvi predstavnik WP1 je Timothy Papadopoulos (Univerza na Cipru) osvetlil glavna metodološka vprašanja prekjezičnega raziskovanja bralnega razvoja. Da je primerjava obstoječih evropskih praks izziv tudi zaradi različnih sociolingvističnih situacij, v katerih so jeziki (kakor tudi njihovi govorci) v različnih razmerjih moči, kar se v praksi odraža tudi pri opismenjevanju, je izpostavila Rhona Winifred Stainthorp (Univerza $\mathrm{v}$ Readingu). Podobno je o izzivih večjezičnosti $\mathrm{v}$ povezavi $\mathrm{z}$ opismenjevanjem govoril tudi Charles Mifsud (Univerza na Malti).

Predstavniki WP2 so k predstavitvam pristopili nekoliko bolj operativno. Vodje vsake od delovnih ekip so predstavili motivacijo za izbiro tematike, rezultate predhodnih pogovorov znotraj ekipe in cilje za nadaljevanje dela. Bojana Petric (Univerza v Essexu) je na tak način predstavila cilje skupine, ki bo raziskovala znanstveno pisanje, Luís Pereira (Univerza v Coventryju) cilje skupine, ki bo raziskovala digitalno pismenost, in Eva Lindgren (Univerza Umeå) cilje skupine, ki bo raziskovala večjezično pismenost.

Prvi dan konference so zaključile predstavitve WP3. Marie-Laure Barbier (ESPE) je predstavila raziskavo, kako priprava študentskih zapiskov s pomočjo digitalnih naprav vpliva na procesiranje informacij. David Galbraith (Univerza v Southamptonu) je prikazal, kako je mogoče uporabiti metodo beleženja tipkanja (ang. keystroke logging) za raziskave razmerja med procesom pisanja in razvojem razumevanja vsebine ter kvalitete besedila. Nazadnje sem Špela Arhar Holdt predstavila razvojni korpus Šolar kot podatkovni vir za raziskave razvoja pisne zmožnosti šolajoče se populacije in 
učiteljskih praks popravljanja pisnih izdelkov, kot tudi vrednost korpusnega gradiva za razvoj oz. dopolnitev uporabnojezikoslovnih izdelkov (učnih gradiv in orodij ter jezikovnih priročnikov).

Drugi dan konference so bile aktivnosti organizirane vzporedno. Dopoldne smo si udeleženci za udeležbo izbrali eno od petih okroglih miz, ki so bile posvečene razpravi glede nadaljnjega dela v sklopu ELN. V popoldanskem času smo si izbrali enega od dveh interaktivnih panelov, kjer so raziskovalci v krajših predstavitvah poročali o dobrih praksah in glavnih izzivih, tipično na ravni posameznih držav. Predstavitev je bilo skupno 18, povzetki pa so na voljo na strani: http://www.is1401eln.eu/en/events-2/conferences-workshops/abstracts/.

\section{SLOVENIJA V ELN}

V ELN trenutno sodeluje 33 evropskih držav, poleg tega pa še 11 držav iz bližnje ali daljne evropske soseščine. V organizacijskem odboru Slovenijo predstavljata doktorici Lidija Magajna in Marija Kavkler (Pedagoška fakulteta UL), kot nadomestni članici pa še doktorici Milena Košak Babuder (Pedagoška fakulteta UL) in Špela Arhar Holdt (Zavod za uporabno slovenistiko Trojina in Filozofska fakulteta UL). Predstavnice PEF so kot strokovnjakinje s področja inkluzije in učnih težav s področja branja in pisanja vključene v WG1, zadnja pa sem se kot raziskovalka s področja korpusnega jezikoslovja pridružila WG3. Poudariti je treba, da je znotraj mreže še veliko prostora za predstavnike slovenskih raziskovalnih ekip, ki se ukvarjajo s katero od v poročilu omenjenih tematik in so pripravljene aktivno sodelovati pri zagotavljanju ciljev, ki si jih je zastavila ELN. Ob premisleku o morebitni vključitvi bodo v pomoč informacije na spletni strani ELN: http://www.is1401eln.eu/en/, kjer bodo v kratkem objavljene tudi novice glede naslednjih srečanj in sestankov skupine. 
To delo je ponujeno pod licenco Creative Commons: Priznanje avtorstvaDeljenje pod enakimi pogoji 2.5 Slovenija.

This work is licensed under the Creative Commons Attribution ShareAlike 2.5 License Slovenia.

http://creativecommons.org/licenses/by-sa/2.5/si/

(c) (i) () 